\title{
Explaining Soil Fertility Heterogeneity in Smallholder Farms of Southern Ethiopia
}

\author{
Fanuel Laekemariam ${ }^{1}{ }^{1}$ and Kibebew Kibret ${ }^{2}$ \\ ${ }^{1}$ Department of Plant Science, Wolaita Sodo University, P.O. Box 138, Wolaita Sodo, Ethiopia \\ ${ }^{2}$ School of Natural Resources Management and Environmental Science, Haramaya University, P.O. Box 138, \\ Dire Dawa, Ethiopia \\ Correspondence should be addressed to Fanuel Laekemariam; laeke2005@yahoo.com
}

Received 14 February 2020; Revised 24 March 2020; Accepted 1 May 2020; Published 13 May 2020

Academic Editor: Teodoro M. Miano

Copyright (c) 2020 Fanuel Laekemariam and Kibebew Kibret. This is an open access article distributed under the Creative Commons Attribution License, which permits unrestricted use, distribution, and reproduction in any medium, provided the original work is properly cited.

\begin{abstract}
Soil is spatially heterogeneous and needs site-specific management. However, soil nutrient information at larger scale in most cases is lacking. Consequently, fertilizer advisory services become dependent upon blanket recommendation approach. Subsequently, it affects yield and profitability. This study is aimed at explaining soil fertility heterogeneity in Wolaita zone, Southern Ethiopia. About 789 soil samples were collected to evaluate soil physical (color, particle size, and bulk density) and chemical properties ( $\mathrm{pH}, \mathrm{OC}, \mathrm{N}, \mathrm{P}, \mathrm{K}, \mathrm{Ca}, \mathrm{Mg}, \mathrm{B}, \mathrm{Cu}, \mathrm{Fe}, \mathrm{Mn}, \mathrm{Zn}, \mathrm{PBS}$, and CEC). The laser diffraction method for soil particles and midinfrared diffused reflectance (MIR) spectral analysis for OC, TN, and CEC determination were employed. Mehlich-III extraction and inductively coupled plasma (ICP) spectrometer measurement were used for the remaining elements. The result based on principal component analysis showed that $52 \%$ of the total variations were explained by exchangeable bases, $\mathrm{CEC}, \mathrm{pH}$, available $\mathrm{P}$, $\mathrm{Cu}, \mathrm{B}$, and particle sizes. Clay texture and acidic soil reaction are dominant. Soil parameters with the following ranges were found at low status: soil OC (0.2-6.9\%), total N (0.01-0.7\%), available P (0.1-238 mg/kg), S (4-30 mg/kg), B (0.01-6.9 mg/kg), and Cu (0.01-5.0 mg/kg). Besides, low levels of exchangeable $\mathrm{Ca}, \mathrm{Mg}$, and $\mathrm{K}$ (Mg-induced $\mathrm{K}$ deficiency) on 22, 34, and 54\% soil samples, respectively, were recorded. The soil contained sufficient Fe, Zn, and $\mathrm{Mn}$. In conclusion, the study aids in developing practical decision for optimum soil management interventions and overcomes lower productivity occurring due to fertilizer use that is not tailored to the local conditions. Overall, continuous cropping, low return of crop residues, and low and/or no fertilizer application might have caused the low status of N, P, K, S, B, and Cu. Therefore, application of inorganic fertilizers specific to the site, lime in acidic soils, and organic fertilizers are recommended to restore the soil fertility and improve crop productivity.
\end{abstract}

\section{Introduction}

In this planet, soil is one of the important resources. Healthy soil is key component to the efficient utilization of soil nutrients in the production of food in sustainable manner. Soil properties vary within the farmland or at the landscape scale $[1,2]$. The causes for spatial variation are both inherent soil-landscape and human-induced across farms differing in resources and practices [3, 4]. Information on spatial heterogeneity of soil properties within farmland/landscape scale is crucial in determining production constraints and taking appropriate management practices [3].

The livelihood of Ethiopian population is based on agriculture as it supports over $80 \%$ of the Ethiopian population
[5]. The sector is still characterized by low input and low yield $[5,6]$. Having healthy soil has a paramount importance to sustainable livelihood. Nevertheless, studies conducted in different parts of Ethiopia have pointed out that soil-related problems such as erosion [7] and continuous cultivation without addition of external inputs [6-9] have been the major constraints to improving farm productivity and farmer livelihoods.

The soil loss due to erosion in Ethiopian highlands was high, varying between $42 \mathrm{t} / \mathrm{ha} / \mathrm{yr}$ and $175.5 \mathrm{t} / \mathrm{ha} / \mathrm{yr}$ [7]. Earlier study on nutrient balance in the country indicated $-122 \mathrm{~N} \mathrm{~kg}$ nitrogen $(\mathrm{N}),-13 \mathrm{~kg}$ phosphorus $(\mathrm{P})$, and $-82 \mathrm{~kg} /$ ha potassium $(\mathrm{K})$ per year [10] signifying large rates of macronutrient depletion. In addition, loss of organic matter 
$(\mathrm{OM})$, macro- and micronutrient depletion, acidity, and deterioration of physical soil properties were also reported [8]. This indicates that interventions targeting poor soil fertility must be designed to improve the success of agriculture. In this regard, up-to-date assessments of soil properties at scales relevant for decision-making and management, including properties that are dynamic and hence change in response to management, are needed [11].

Owing to differences in farming topography, soil management practices, inherent soil properties, and biophysical and socioeconomic conditions [4], soil heterogeneity at farm level and in vast areas of agricultural lands is expected to occur. However, at local scale, the information on soil nutrient contents and nutrient availability is limited. Consequently, the soil management interventions are subjected to blanket recommendation approach. The approach is not suitable to farmers as it does not take sufficient layers of complexity into account [4]. Any advice about fertilizers, especially to resource-poor smallholder farmers, needs to consider soil conditions at farm scales in order to maximize yield and profitability. Hence, this study aims to quantify the soil nutrient status of agricultural lands and explain the relationship with soil management practices for improved efficiency of fertilizer advisory services.

\section{Materials and Methods}

2.1. Description of the Study Area. The study was conducted in three adjacent and potential districts of Wolaita zone, Southern Nations, Nationalities, and Peoples' Regional State (SNNPRS) of Ethiopia, namely, Damot Gale, Damot Sore, and Sodo Zuria (Figure 1). The area is located between $037^{\circ} 35^{\prime} 30^{\prime \prime}-037^{\circ} 58^{\prime} 36^{\prime \prime} \mathrm{E}$ and $06^{\circ} 57^{\prime} 20^{\prime \prime}-07^{\circ} 04^{\prime} 31^{\prime \prime} \mathrm{N}$. A total of 82 kebeles were surveyed: 31 from Damot Gale, 18 from Damot Sore, and 33 from Sodo Zuria district. The total study area covers about 84,000 hectares (ha). The area has a bimodal rainfall pattern with mean annual precipitation of $1355 \mathrm{~mm}$. The mean monthly temperature ranges from 17.7 to $21.7^{\circ} \mathrm{C}$ with an average of $19.7^{\circ} \mathrm{C}$. The elevation varies between 1473 and 2873 meter above sea level (m.a.s.l.) with mid-highland (1500-2300 m.a.s.l.) agroecology (Figure 2). Eutric Nitisols associated with humic Nitisols are the most prevalent soils in Wolaita zone [12]. These soils are dark reddish brown with a deep profile [13]. Agriculture is predominantly small-scale mixed subsistence farming and is being rainfed. Continuous cultivation without any fallow periods coupled with complete removal of crop residues is a common practice on cultivated fields.

2.2. Soil Sampling Procedure and Laboratory Analysis. Geographical information system (GIS) was employed to randomly assign predefined sampling locations. A total number of 789 preidentified sampling points were generated and displayed over the study area. During survey work, the predefined sample locations were navigated using geographical positioning system receiver (model Garmin GPSMAP 60Cx).
Once the sampling point was navigated, sampling depth was $0-20 \mathrm{~cm}$ for tef (Eragrostis tef (Zucc.) Trotter), haricot bean (Phaseolus vulgaris L.), wheat (Triticum aestivum L.), maize (Zea mays L.), grazing spp., etc., while it extended to $50 \mathrm{~cm}$ for perennial crops such as enset (Ensete ventricosum) and coffee (Coffea arabica L.). About 10 to 15 subsamples were taken based on the complexity of topography and heterogeneity of the soil type using soil auger, and then one kilogram (kg) composite was taken for laboratory analysis. During sample collection, hot spot areas (manure and crop threshing sites) were excluded. To reduce the potential for cross-sample contamination, the soil auger and other sampling tools were cleaned before taking the next sample at different locations. For soil bulk density determination, undisturbed soil samples using core-sampler were collected.

2.3. Sample Preparation and Soil Analysis. After soil processing (drying, grinding, and sieving), soil physicochemical properties like particle size distribution (PSD), $\mathrm{pH}$, soil organic carbon (OC), macro- and micronutrient contents, and cation exchange capacity (CEC) were analyzed. Particle size distribution, $\mathrm{pH}, \mathrm{OC}, \mathrm{TN}$, and CEC were analyzed at the National Soil Testing Center (NSTC), Addis Ababa, Ethiopia, while $\mathrm{Ca}, \mathrm{Mg}, \mathrm{K}, \mathrm{Na}, \mathrm{B}, \mathrm{Cu}, \mathrm{Fe}, \mathrm{Mn}$, and $\mathrm{Zn}$ were analyzed in Altic BV, Dronten, Netherlands.

The soil color (dry) was described using Munsell soil color chart during the noon hours [14]. Soil bulk density (BD) was determined using core method as described by Anderson and Ingram [15]. PSD was analyzed by laser diffraction method using laser scattering particle size distribution analyzer (Horiba, Partica LA-950V2) [16]. A teaspoon of soil (approximately $10 \mathrm{~g}$ ) sieved through $2 \mathrm{~mm}$ was introduced into the dispersion unit of the laser particle analyzer for measurement. The soil sample was run in a wet mode using deionized water and $1 \%$ sodium hexametaphosphate (Calgon) solution as dispersing agent. To maintain the random orientation of particles in suspension, automatic ultrasonication was applied. All the required operations were controlled by a personal computer. The LA950 software version 7.01 for Windows [17] was used to run the analysis. For each sample, four consecutive readings were taken within 15-minute duration. The readings were converted to \% (sand, silt, and clay), using the appropriate script on the R language and environment for statistical computing [18]. The fourth reading that was taken after continuous agitation of the particles was considered as final data for the particle size distribution.

Soil $\mathrm{pH}(1: 2$ soil : water suspension) was measured with a glass electrode (model CP-501) [19]. For soils having $\mathrm{pH}<5.5$, exchangeable acidity was measured using the method described by Sahlemedhin and Taye [20]. Available $\mathrm{P}$, available $\mathrm{S}$, exchangeable basic cations $(\mathrm{Ca}, \mathrm{K}, \mathrm{Mg}$, and sodium ( $\mathrm{Na})$ ), and extractable micronutrients (Fe, manganese $(\mathrm{Mn}), \mathrm{Zn}, \mathrm{Cu}$, and $\mathrm{B}$ ) were determined using MehlichIII multinutrient extraction method [21]. The concentration of elements in the supernatant was measured using inductively coupled plasma (ICP) spectrometer. The available 


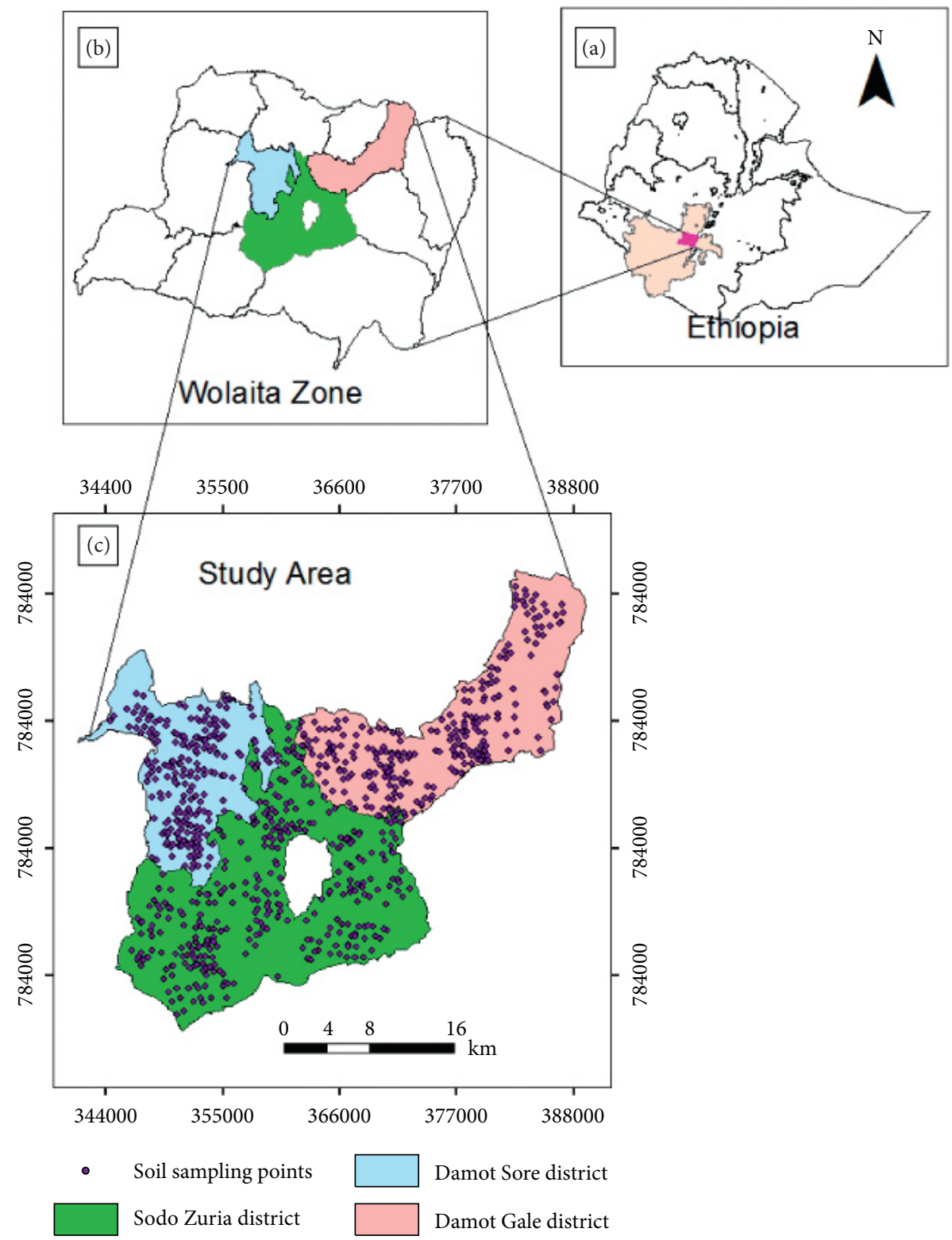

FIGURE 1: The location map of Wolaita zone in Ethiopia (a), study districts in Wolaita zone (b), and soil sampling points in the study areas (c).

soil Mn content was determined using manganese activity index (MnAI) as described by Karltun et al. [22]:

$$
\text { MnAI }=101.7-(15.2 * \mathrm{pH})+3.75 * \text { Mn_soil, }
$$

where $\mathrm{pH}$ is $\mathrm{pH}\left(\mathrm{H}_{2} \mathrm{O}\right)$ and $\mathrm{Mn} \_$soil the concentration of Mehlich-III extracted manganese.

The same samples used for wet chemistry were also subjected to MIR spectral analysis to determine the amount of soil OC, total N, and CEC. For MIR spectral analysis, soil samples were ground using Retsch mortar grinder RM 200 to size smaller than $0.5 \mathrm{~mm}$. Soil samples weighing $0.035 \mathrm{~g}$ were loaded in a single well, and one sample was loaded in four consecutive wells of an aluminum microplate having 96 wells.
The sample surface was gently pressed, leveled, and smoothed using a microspatula (a rounded, smooth surface glass rod). The absorbance of diffused reflectance spectra was scanned using the HTS-XT accessory of a Bruker-TENSOR 27 spectrometer. The background (i.e., soil sample-free well) was scanned using roughened surface well of the aluminum microplate. Absorbance spectra of the entire soil samples were measured using OPUS version 7.0 software [23] with 32 scans and spectral range of $7400-600 \mathrm{~cm}^{-1}$ (wave numbers) including part of near infrared (NIR) region. The spectrum acquisition took an hour per plate. The MIR region spectra in the wave number range of $4000-600 \mathrm{~cm}^{-1}(2500-16667 \eta \mathrm{m})$ were used to predict soil properties. Quantitative analysis of the 


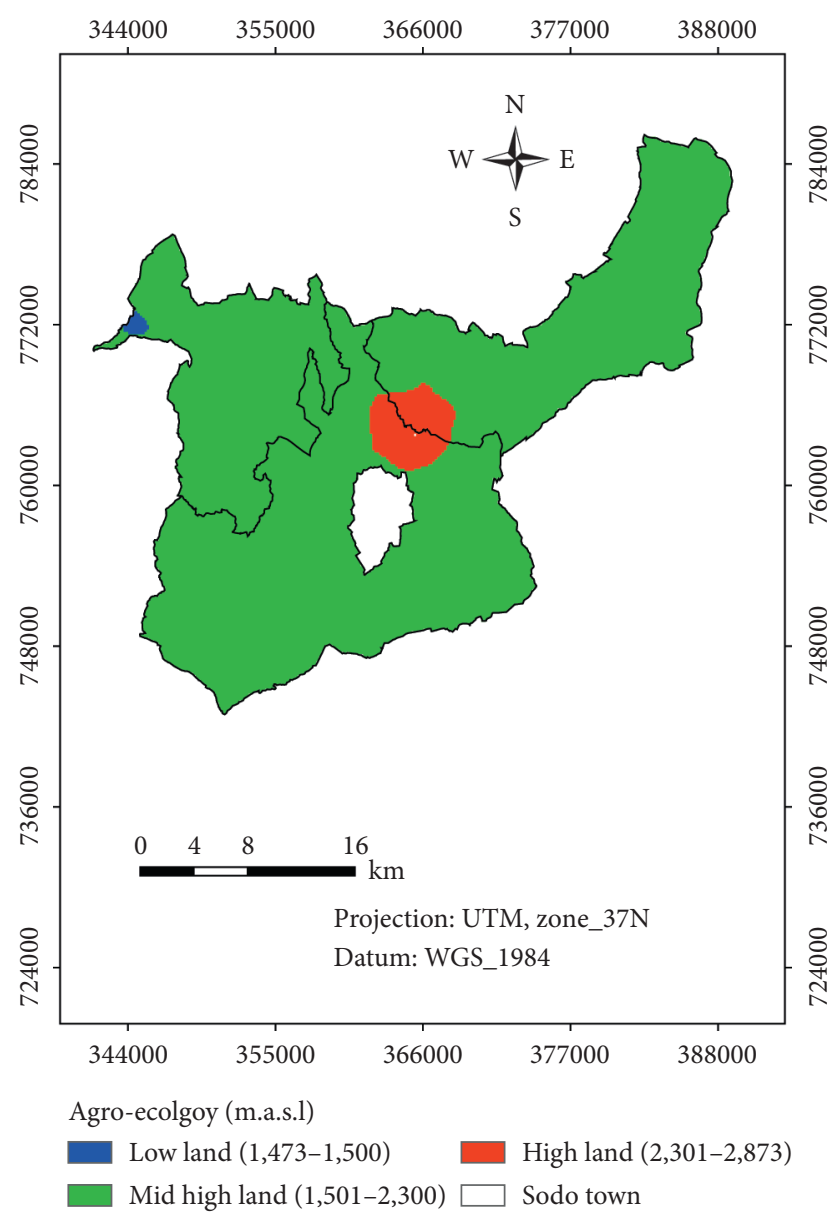

Figure 2: Agroecology of the study area.

spectra was done using Quant 2 evaluation function of OPUS (software version 7) to predict the concentration of OC, TN, and CEC. The average of four consecutive scans of each parameter was taken as predicted data for the report.

2.4. Statistical Analyses. Principal component analysis (PCA) was run to group related soil properties and explain most of the variance with a small set of variables. The Kaiser-Meyer-Olkin measure (KMO) of sampling adequacy was performed prior to PCA. Descriptive statistics such as mean, standard deviation, minimum, maximum, median, and percentage was employed. In addition, analysis of variance test, Pearson's correlation, and regression analyses were performed to evaluate relationships among the soil properties. Variation in soil properties was determined using the coefficient of variation $(\mathrm{CV})$ and rated as low $(<20 \%)$, moderate $(20-50 \%)$, and highly variable $(>50 \%)$ according to Amuyou et al. [24]. For the management purposes, interpretation of the results was given using proper ratings. Data analysis was carried out using Microsoft Excel and Statistical Package for the Social Sciences (SPSS) software version 20.

\section{Results and Discussion}

3.1. Principal Component Analysis of Soil Properties. The KMO values of PCA were 0.75 for Damot Gale, 0.69 for Damot Sore, 0.69 for Sodo Zuria, and 0.70 overall. The values were above 0.6 indicating that the sample size was adequate to run PCA, and the result is presented in Table 1 and Figures 3(a)-3(d). In Damot Gale district, 57\% of the total variation was explained by PCA 1 and PCA 2. In Damot Sore district, PCA 1 and PCA 2 together were able to explain $53 \%$ of the total variation. In Damot Sore district, PCA 1 and PCA 2 together were able to explain 53\% of the total variation. Overall, the first two components explained $52 \%$ of the variance among soil properties, of which component 1 explained $32 \%$ while the second explained $20 \%$.

The most important variables accounting for soil variability were exchangeable bases ( $\mathrm{Ca}, \mathrm{Mg}, \mathrm{K}), \mathrm{CEC}$, soil $\mathrm{pH}$, available $\mathrm{P}, \mathrm{Cu}$, and soil particle size. These variables could be associated with both inherent soil-landscape (e.g., clay mineralogy and topography) and human-induced factors (e.g., soil management practices and land use types) $[1,2,6,25,26]$.

Nitisols are dominant in the study area in which their clay assemblage is dominated by kaolinite [13]. These clay minerals have $\mathrm{pH}$-dependent charges [27]. Thus, the association between soil $\mathrm{pH}$ and increase in CEC might be linked with the presence of $\mathrm{pH}$-dependent charges, probably kaolinite clay mineralogy [27]. The soil $\mathrm{pH}$ in the present study also covaried with and influenced CEC, exchangeable bases ( $\mathrm{Ca}, \mathrm{Mg}, \mathrm{K}$ ), available $\mathrm{P}$, and $\mathrm{Cu}$. This is evidenced by the significant $(p \leq 0.001)$ and positive correlation between soil $\mathrm{pH}$ and available $\mathrm{P}(r=0.44), \mathrm{Ca}(r=0.66), \mathrm{Mg}(r=0.52), \mathrm{K}$ $(r=0.65), \mathrm{Cu}(r=0.27), \mathrm{B}(r=0.33)$, and CEC $(r=0.53)$. Similarly, Maria and Yost [28] and Joao et al. [29] observed variation in the soil CEC along with soil $\mathrm{pH}$.

Difference in particle size distribution and soil textural classes might be the reason for appearance as an important source of variability. Clay content was found to show a significant and inverse relationship with sand $(r=-0.8)$, silt $(r=-0.98), \mathrm{pH}(r=-0.3)$, available $\mathrm{P}(r=-0.3)$, and $\mathrm{Ca}$ $(r=-0.3)$. This would imply that the higher clay content might be associated with gradual accumulation of acidic cation such as exchangeable $\mathrm{Al}, \mathrm{H}$, and oxides of $\mathrm{Al}$ and $\mathrm{Fe}$. This results in $\mathrm{P}$ fixation and reduces its availability $[2,30]$. Besides, the negative correlation between clay and $\mathrm{Ca}$, according to Tabu et al. [31], indicates the dominance of low activity clay minerals that predispose it to leaching of exchangeable bases.

\subsection{Soil Physical and Chemical Properties}

3.2.1. Selected Soil Physical Properties. The hue index was 2.5 YR, $5 \mathrm{YR}, 7.5 \mathrm{YR}$, and $10 \mathrm{YR}$. The value index of most samples was between 3 and 5 whereas chroma was between 3 and 4 (Figure 4). Damot Gale district soil has dominantly brown color whereas soils in Damot Sore and Sodo Zuria districts have shown brown, dark reddish brown, and reddish brown colors. Combining the indices, brown, dark reddish brown, reddish brown, and gray soil colors were observed. Light reflection tends to increase on brown and reddish soil colors and results in increase of color value. Similarly, purity of spectral colors increases 
TABLE 1: Eigen value and explained variances of PCA for the study districts in Ethiopia during 2013.

\begin{tabular}{|c|c|c|c|c|c|c|c|c|c|c|c|c|}
\hline \multirow{3}{*}{ PCA } & \multicolumn{12}{|c|}{ Location } \\
\hline & \multicolumn{3}{|c|}{ Damot Gale } & \multicolumn{3}{|c|}{ Damot Sore } & \multicolumn{3}{|c|}{ Sodo Zuria } & \multicolumn{3}{|c|}{ Total } \\
\hline & Eigen value & $\operatorname{Var}(\%)$ & Cum \% & Eigen value & $\operatorname{Var}(\%)$ & Cum \% & Eigen value & $\operatorname{Var}(\%)$ & Cum \% & Eigen value & $\operatorname{Var}(\%)$ & Cum \% \\
\hline 1 & 7 & 41 & 41 & 6 & 33 & 33 & 5 & 30 & 30 & 5 & 32 & 32 \\
\hline 2 & 3 & 16 & 57 & 3 & 20 & 53 & 4 & 21 & 51 & 3 & 20 & 52 \\
\hline 3 & 2 & 14 & 71 & 2 & 14 & 67 & 2 & 14 & 65 & 2 & 13 & 65 \\
\hline 4 & 1 & 7 & 78 & 1 & 8 & 75 & 1 & 6 & 72 & 1 & 7 & 72 \\
\hline
\end{tabular}

Var: explained variance; Cum: cumulative variance.

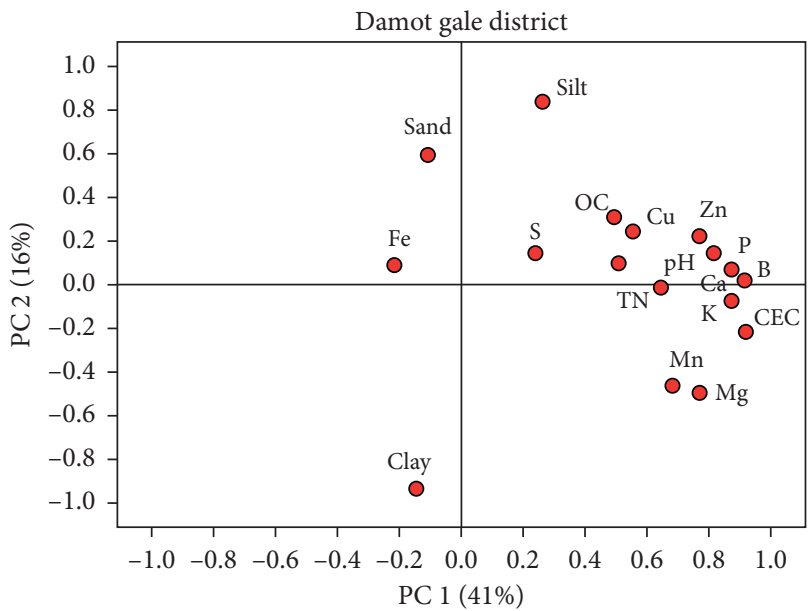

(a)

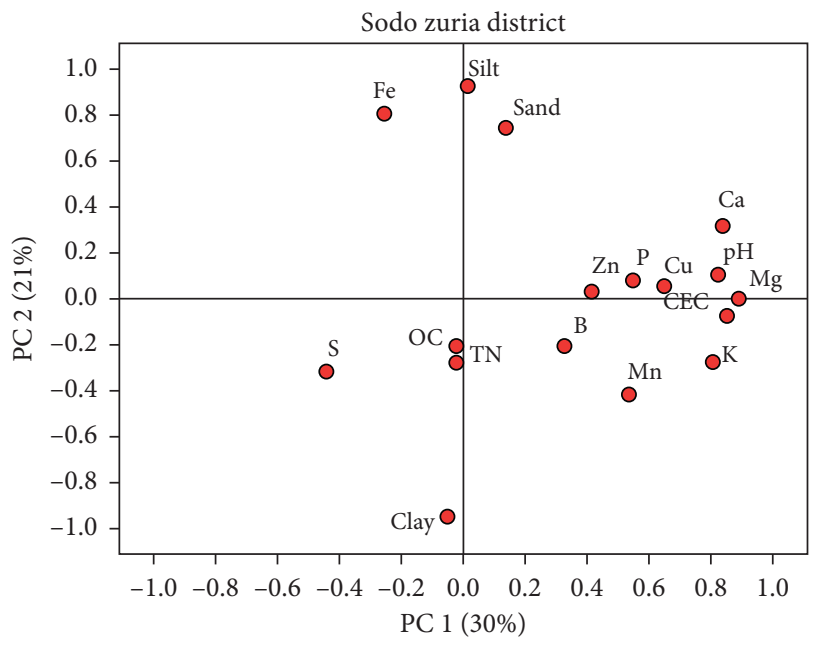

(c)

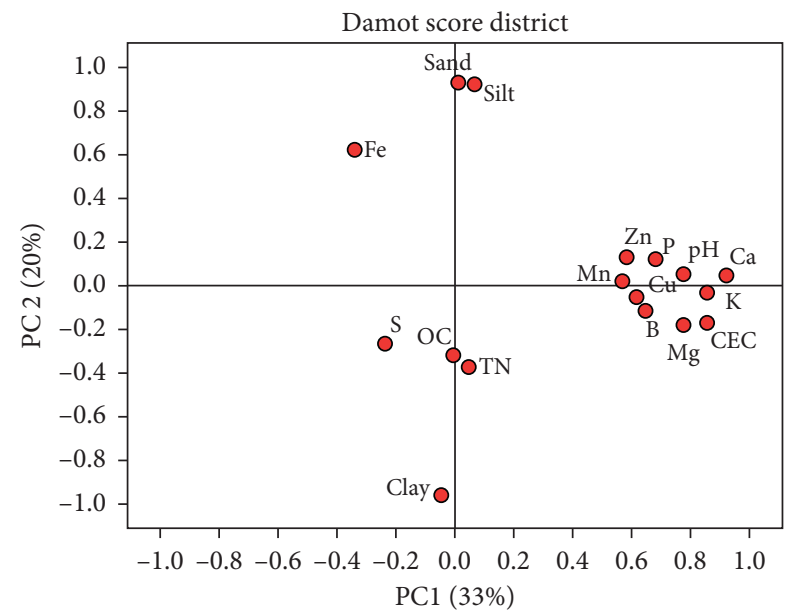

(b)

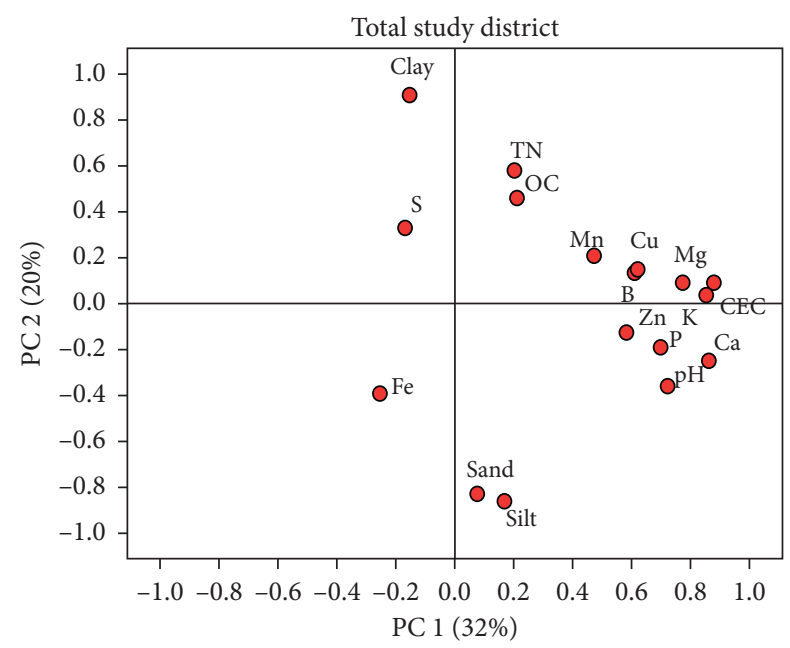

(d)

Figure 3: Component plot of soil properties of Damot Gale (a), Damot Sore (b), Sodo Zuria (c), and total study area (d).

with increase in reflection resulting in an increase of the chroma.

The soil colors in the studied soils might reflect the low status of soil OM and influence of oxidized Fe. Higher content of $\mathrm{Fe}$ in Nitisols would result in red or reddish brown soil colors [13]. Analogously, Desbiez et al. [32] found higher value and chroma for red and least fertile soils, and lower value and chroma for darker and fertile soils. Though caution is needed, the perception of considering reddish colors as less fertile soil by farmers than the darker soil colors has also been stated by Desbiez et al. [32], Pound and Jonfa [33], and Hailesilase et al. [34].

Results on soil particle size distribution, textural classes, and bulk density (BD) are presented in Table 2. Statistically significant differences $(p<0.001)$ among sampled soils were recorded. The mean particle size distribution was silt $>$ clay $>$ sand (Damot Gale) and clay $>$ silt $>$ sand (Damot Sore and Sodo Zuria). The dominant textural class is silty loam (Damot Gale) and clay (Damot Sore and Sodo Zuria) (Table 2 and Figure 5). The silt/clay ratio was above 0.8 


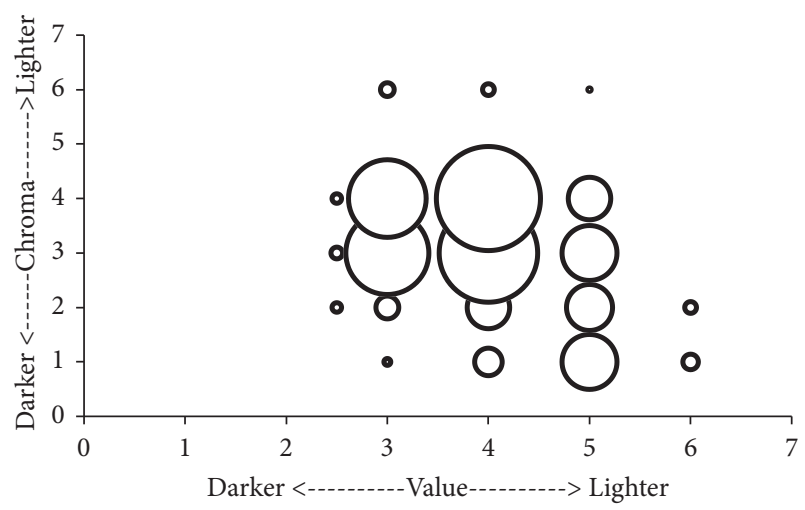

FIGURE 4: Soil color value and chroma indices of samples collected from Damot Gale, Damot Sore, and Sodo Zuria districts in Ethiopia. The size of each bubble is proportional to the number of samples at the corresponding value/chroma combination.

(Table 2). According to Young [35], a ratio of silt/clay greater than 0.15 indicated young soil, not highly weathered and having easily weatherable minerals. However, soil samples are from Nitisols which are known to have relatively advanced weathering [13]. This implies that the clay in the upper surface soil might have been translocated to the deeper layer or removed by erosion to cause higher silt/clay ratio. In agreement with this, the report of Alemayehu and Sheleme [36] in Sodo Zuria district revealed a high silt/clay ratio with a relative reduction with depth.

The soil bulk density (BD) varied with soil textural classes. Soils with silty loam textural classes had lower BD values than those with clay textural classes. This is evidenced by significant $(p<0.01)$ correlation of $\mathrm{BD}$ with silt $(r=-0.44)$ and clay (0.43) particles. Soil BD also showed significantly $(p<0.01)$ inverse relation with soil $\mathrm{OM}$ $\left(r=-0.33^{*}\right)$, which is in agreement with Oguike and Mbagwu [37] and Gajic et al. [38].

Bulk density influences soil physical properties, particularly soil-water movement, aeration, and root proliferation. The soil $\mathrm{BD}$ values of the silty loam textured soils varied from 0.76 to $1.48 \mathrm{~g} / \mathrm{cm}^{3}$, whereas on clay textured soils it was from 0.76 to $1.52 \mathrm{~g} / \mathrm{cm}^{3}$. Hazelton and Murphy [39] indicated 1.6 and $1.4 \mathrm{~g} / \mathrm{cm}^{3}$ as critical BD values for loam/clay loam and clay textures, respectively. Thus, soils are satisfactory for plant growth and root restriction because compaction would be less likely to occur.

3.2.2. Soil $\mathrm{pH}$ and Exchangeable Acidity. Soil $\mathrm{pH}$ ranged from 4.5 (strongly acidic) to 8.0 (moderately alkaline) with low variability among soil samples $(\mathrm{CV}<20 \%)$ (Table 3 ). About $21 \%$ of total samples had $\mathrm{pH}<5.5$ (strongly acidic reaction), 53.3\% [moderately acidic (5.6-6.5)], 22.7\% [neutral (6.6-7.3)], and $3.06 \%$ [moderately alkaline (7.4-8.4)] based on EthioSIS [40] ratings. Most nutrients for field crops are available at $\mathrm{pH}$ value between 5.5 and 8.0 [41], and the optimal $\mathrm{pH}$ for many plant species in absence of free exchangeable $\mathrm{Al}$ is 5.5 to 6.8 [42]. Nevertheless, crops can differently adapt below and above optimum $\mathrm{pH}$ values.
Generally, the study area is categorized under acidic soil reaction of varying degree. This might be due to the leaching of basic cations, removal of bases by crop harvest, and $\mathrm{Al}$ hydrolysis. Various research results showed that basic cations removal through crop harvest [30,43, 44], leaching due to excessive precipitation, steepness of the topography, application of inorganic fertilizer [44, 45], and mineralization and formation of humic substances [46] were reported as causes for soil acidity formation. Cardelli et al. [47] and Alexandra et al. [48] also indicated that $\mathrm{H}^{+}$ion released through nitrification of $\mathrm{NH}_{4}{ }^{+}$sourced fertilizers on cultivated lands might also encourage the development of lower $\mathrm{pH}$.

Under strongly acidic soils, hydrolysis of $\mathrm{Al}$ and a sharp increase in exchangeable $\mathrm{Al}$ are expected [49]. This process releases $\mathrm{H}^{+}$ions that further lower the soil $\mathrm{pH}$ to a level that seriously affects the availability of certain nutrient elements, such as $\mathrm{P}$, and increases $\mathrm{Al}$ and Fe toxicity. Significant $(p \leq 0.001)$ and positive correlation between $\mathrm{pH}$ and available $\mathrm{P}(r=0.4)$ was also recorded (Table 4$)$.

The exchangeable acidity $(\mathrm{cmol}(+) / \mathrm{kg})$ varied from nil to 5.1 whereas the acid saturation (\%) ranged from 0 to 21 (Table 3). The exchangeable acidity and acid saturation were higher in clay textured soils than silty loam soils, and the permissible acid saturation (PAS) which is crop tolerance level for annual crops growing in Ethiopian soil is 10\% [50]. This value is used for determination of lime rate. Generally, strongly acidic soils should be managed using lime, whereas on moderately acidic soil lime can be applied, but looking for acid-tolerant crop varieties is also suggested.

3.2.3. Soil OC, TN, and Available P and S. The soil OC (\%) ranged from 0.2 to 6.9 (Table 5). This may reflect differences in organic matter management. About $48 \%, 51 \%$, and $1 \%$ of soil samples contain very low $(<2 \%)$, low $(2-4 \%)$, and moderate $(4-10 \%)$ OC based on the rating suggested by Landon [41]. The very low to low estimated OC might be due to complete removal of crop residues and no addition of external organic material inputs such as compost or manure. In conformity with this, complete removal of aboveground biomass, continuous tillage, insufficient application of organic inputs, and heavy grazing were reported as the major reasons for extremely low soil OC in Ethiopian soils $[2,6,26,51]$.

The lower soil OC could result in poor aggregate stability and thereby aggravate soil degradation [38] and also influence soil macro- and micronutrient reserves. Using simple aggregate stability estimation equation $(\% \mathrm{OM} \times 100 / \%$ clay $\leq)$ [52], the soil OM on about $62 \%$ of the sampled fields does not contribute to soil aggregate stability. This implies that soil particles are more likely to be detached with erosion. Hence, farming practices that improve soil OC are encouraged.

Total nitrogen varied between 0.01 and $0.7 \%$ (Table 5), but most soils contain very low $(<0.1)$ to low $(0.1-0.15)$ TN based on the ratings suggested by EthioSIS [40]. TN followed the trend of soil OC. Pearson correlation matrix shows that OC was positively and significantly correlated with TN $(r=0.95)$ (Table 4$)$. The $\mathrm{C}$ to $\mathrm{N}$ ratio of soil samples varied 
TABLE 2: Descriptive statistics of particle size distribution, silt: clay ratio, and bulk density for surface soils.

\begin{tabular}{|c|c|c|c|c|c|c|c|}
\hline District & Descriptive statistics & Sand & Silt & Clay & Silt: clay ratio & ${ }^{*} \mathrm{BD}\left(\mathrm{g} / \mathrm{cm}^{3}\right)$ & Soil textural classes \\
\hline \multirow{6}{*}{ Damot Gale $(N=243)$} & Mean & 18.4 & 56.2 & 25.4 & 3.2 & 1.14 & \multirow{6}{*}{ Silt loam } \\
\hline & Std. dev & 6.6 & 10.6 & 13.7 & 2.1 & 0.12 & \\
\hline & Median & 17.3 & 58.0 & 21.7 & 2.8 & 1.13 & \\
\hline & Minimum & 0.5 & 17.0 & 6.1 & 0.2 & 0.76 & \\
\hline & Maximum & 39.5 & 78.6 & 79.9 & 10.7 & 1.48 & \\
\hline & CV (\%) & 36 & 19 & 54 & 66 & 11 & \\
\hline \multirow{6}{*}{ Damot Sore $(N=216)$} & Mean & 12.0 & 24.7 & 63.3 & 0.4 & 1.23 & \multirow{6}{*}{ Clay } \\
\hline & Std. dev & 4.1 & 7.8 & 11.4 & 0.2 & 0.13 & \\
\hline & Median & 13.2 & 24.7 & 62.1 & 0.4 & 1.22 & \\
\hline & Minimum & 2.8 & 7.3 & 32.5 & 0.1 & 1.04 & \\
\hline & Maximum & 23.3 & 47.9 & 89.7 & 1.5 & 1.52 & \\
\hline & CV (\%) & 34 & 32 & 18 & 50 & 11 & \\
\hline \multirow{6}{*}{ Sodo Zuria $(N=331)$} & Mean & 11.4 & 21.6 & 67.0 & 0.4 & 1.20 & \multirow{6}{*}{ Clay } \\
\hline & Std. dev & 4.3 & 10.0 & 13.0 & 0.3 & 0.13 & \\
\hline & Median & 11.5 & 19.6 & 69.2 & 0.3 & 1.19 & \\
\hline & Minimum & 1.3 & 3.0 & 28.6 & 0.03 & 0.76 & \\
\hline & Maximum & 30.8 & 51.5 & 95.6 & 1.8 & 1.50 & \\
\hline & CV (\%) & 38 & 46 & 19 & 75 & 11 & \\
\hline \multirow{8}{*}{ Total $(N=789)$} & Mean & 13.7 & 33.1 & 53.2 & 1.3 & 1.18 & \multirow{8}{*}{ Clay } \\
\hline & Std. dev & 5.9 & 18.2 & 22.6 & 1.8 & 0.13 & \\
\hline & Median & 13.1 & 27.5 & 58.8 & 0.5 & 1.17 & \\
\hline & Minimum & 0.5 & 3.0 & 6.1 & 0.03 & 0.76 & \\
\hline & Maximum & 39.5 & 78.6 & 95.6 & 10.7 & 1.52 & \\
\hline & $\mathrm{CV}(\%)$ & 43 & 55 & 42 & 138 & 11 & \\
\hline & $F_{\text {value }}$ & 150 & 1015 & 827 & 503.5 & 18.4 & \\
\hline & $p$ value & 0.000 & 0.000 & 0.000 & 0.000 & 0.000 & \\
\hline
\end{tabular}

${ }^{*}$ Sample size for BD (bulk density) of Damot Gale $=197$, Damot Sore $=42$, Sodo Zuria $=193$, and total $=432$.

from 7 to 41 (Table 5) in which mean ratio was 15 implying that soil OM decomposition proceeded at the maximum rate (if $\mathrm{C} / \mathrm{N}<25$ ) [39].

The lower TN may be ascribed to complete removal of crop residues, less organic input application, and more intensive cultivation. Frequent cultivation would accelerate the higher oxidation rate of soil OM. In general, the existing input use practices could not compensate for the observed mineralization of $\mathrm{OM}$ and $\mathrm{N}$ losses. In line with this finding, Abreha et al. [30], Girma and Endalkachew [53], and Tsehaye and Mohammed [54] reported lower soil TN due to intensive cultivation, less input application, and higher mineralization rate in Ethiopian soils.

Organic matter is the main supplier of soil N, S, and P in low input farming systems. Tiejun et al. [55] and Alexandra et al. [48] reported that changes in soil OM could lead to changes in total $\mathrm{N}$. Long-term cultivation without organic fertilizers leads to a decrease in soil OC and total $\mathrm{N}$ contents because organic matter accounts for more than $95 \%$ of soil $\mathrm{N}$ $[48,55]$. Hence, gradual build-up of soil OM for ensuring sustainable productivity is recommended.

The available $\mathrm{P}(\mathrm{AvP})$ content of soils varied from 0.1 to $238.1 \mathrm{mg} / \mathrm{kg}$ (Table 5). Variation in AvP content among samples could be due to differences in acidity, organic matter content, and $\mathrm{P}$ fertilizer application differences in the soils. However, $83.9 \%$ and $7.3 \%$ of soil samples contained very low $(<15 \mathrm{mg} / \mathrm{kg})$ and low $(15-30 \mathrm{mg} / \mathrm{kg})$ levels of $\mathrm{P}$, respectively, on the basis of EthioSIS [40] ratings. This might be attributed to $\mathrm{P}$ fixation in strongly acid soils [30,56]. Pearson correlation matrix also shows significant $(p \leq 0.001)$ and positive correlation $(r=0.44)$ between available $\mathrm{P}$ and soil $\mathrm{pH}$ (Table 4). Decline of $\mathrm{P}$ in most cultivated soils of Ethiopia resulted from the impacts of low $\mathrm{P}$ fertilizer application rate, massive nutrient depletion through complete crop harvest, low return of crop residues, and soil erosion [6, 30, 51, 53, 57].

In this study, though small, significant $(p \leq 0.001)$ and positive correlation $(r=0.14)$ is observed between available $\mathrm{P}$ and OC (Table 4). Organic materials can be used as soil conditioners due to chelation of $\mathrm{Fe}$ and $\mathrm{Al}$ (hydr) oxides and corresponding release of $\mathrm{OH}^{-}$. Apart from this, organic matter is also one of the pools in the soil. Its mineralization can contribute to available $\mathrm{P}$ [56]. Low soil $\mathrm{OM}$ may therefore imply low available $\mathrm{P}$ if other sources are not there. In addition, the available $\mathrm{P}$ was found to significantly correlate with $\mathrm{Ca}(r=0.5), \mathrm{Mg}(r=0.4), \mathrm{K}(r=0.6), \mathrm{B}(r=0.4)$, $\mathrm{Cu}(r=0.4), \mathrm{Mn}(r=0.2)$, and $\mathrm{Zn}(r=0.5)$ (Table 4$)$. This implies that they have no antagonistic effect on this nutrient. The low $\mathrm{P}$ status in this finding indicates the need for application of $\mathrm{P}$ fertilizer for soils of the study areas.

Soils of the study area contain low available $S(<30 \mathrm{mg} /$ $\mathrm{kg}$ ) (Table 5) based on the ratings suggested by EthioSIS [40]. The correlation analysis also indicated significantly $(p<0.001)$ negative $(r=-0.35)$ and positive $(r=0.25)$ relationship of available $\mathrm{S}$ with $\mathrm{pH}$ and $\mathrm{OC}$, respectively (Table 4). Different authors associated the lower S content with lower OM, as it is the major source of total $\mathrm{S}$ in surface soils [58-61]. In addition, $\mathrm{SO}_{4}{ }^{2-}$ adsorption to $\mathrm{Al}$ and $\mathrm{Fe}$ oxides at lower $\mathrm{pH}$, increasing cropping intensity 

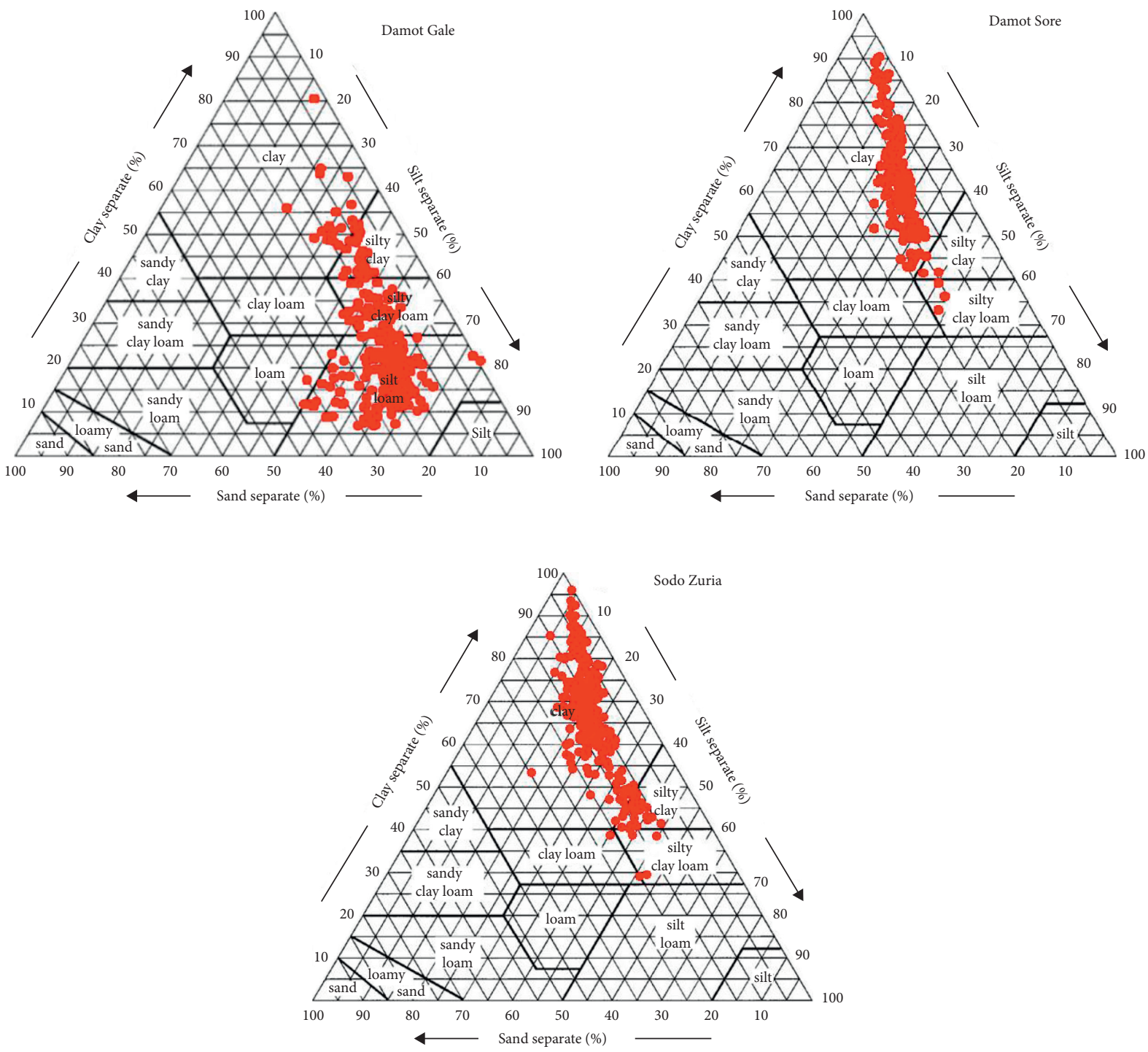

FIGURE 5: Soil textural classes of the study districts in Ethiopia.

[62], and large S uptake by crops [58] were indicated. Furthermore, nonuse of $S$ fertilizers (until recently), removal of crop residues, leaching losses, and lower application of organic fertilizers [58] were also reported to be causes for low level of $S$ for Ethiopian agricultural lands. Hence, maintaining adequate levels of soil OM and external $\mathrm{S}$ application is required for sustainable crop production in the study areas.

3.2.4. Exchangeable Bases, CEC, and PBS. The soil exchangeable bases, CEC, and PBS values of the study areas are presented in Table 6. The distribution on exchangeable bases in the exchange complex has been characterized to be in the order of $\mathrm{Ca}>\mathrm{Mg}>\mathrm{K}>\mathrm{Na}$. This could be related to the charge density as divalent cations $(\mathrm{Ca}$ and $\mathrm{Mg}$ ) have higher affinity towards colloidal sites than monovalent cations ( $\mathrm{K}$ and $\mathrm{Na}$ ). Similar arrangement of cations was also reported by Tsehaye and Mohammed [54], Teshome et al. [51], and Okubay et al. [26].
Exchangeable $\mathrm{Ca}(\mathrm{cmol}(+) / \mathrm{kg})$ across the study area varied from 1 to 31 , and exchangeable $\mathrm{Mg}$ ranged between 0.2 and $9.5 \mathrm{cmol}(+) / \mathrm{kg}$, whereas exchangeable $\mathrm{K}$ and $\mathrm{Na}$ varied from 0.1 to 6.2 and 0.1 to $3.1 \mathrm{cmol}(+) / \mathrm{kg}$, respectively (Table 6). Using the ratings suggested by Landon [41], about $1,21,54,23$, and $1 \%$ of the total samples exhibited very low $(<2)$, low $(2-5)$, medium $(5-10)$, high $(10-20)$, and very high $(>20)$ exchangeable $\mathrm{Ca}(\mathrm{cmol}(+) / \mathrm{kg})$, respectively. Data regarding exchangeable $\mathrm{Mg}(\mathrm{cmol}(+) / \mathrm{kg})$ indicated that 0.5 , $33.6,60.8,4.8$, and $0.3 \%$ of samples across the study areas qualified to be very low $(<0.3)$, low $(0.3-1.0)$, medium $(1.0-3.0)$, high (3.0-8.0), and very high $(>8.0)$ in exchangeable $\mathrm{Mg}$, respectively, as per the ratings of Landon [41]. Based on the suggestion made to Ethiopian soil [40], the proportion of soil exchangeable $\mathrm{K}$ across districts categorized as very low $(<0.2)$, low $(0.2-0.5)$, optimum (0.51-1.5), high (1.51-2.3), and very high $(>2.31)$ was 0.1 , $14.7,57.7,14.8$, and $12.7 \%$, respectively. Additionally, exchangeable sodium percentage values across districts were found below the critical level (15\%). 
TABLE 3: Descriptive statistics of soil pH, exchangeable acidity, and acid saturation for surface soils.

\begin{tabular}{|c|c|c|c|c|}
\hline Districts & Descriptive statistics & $\mathrm{pH}\left(\mathrm{H}_{2} \mathrm{O}\right)$ & Exc. acidity $(\mathrm{cmol}(+) / \mathrm{kg})$ & Acid saturation (\%) \\
\hline \multirow{6}{*}{ Damot Gale $(N=243)$} & Mean & 6.4 & 0.00 & 0.10 \\
\hline & Std. dev & 0.5 & 0.10 & 0.60 \\
\hline & Median & 6.3 & 0.00 & 0.00 \\
\hline & Minimum & 5.2 & 0.00 & 0.00 \\
\hline & Maximum & 8.0 & 1.30 & 7.10 \\
\hline & CV (\%) & 8.0 & - & - \\
\hline \multirow{6}{*}{ Damot Sore $(N=216)$} & Mean & 6.0 & 0.50 & 2.30 \\
\hline & Std. dev & 0.7 & 1.00 & 4.70 \\
\hline & Median & 5.9 & 0.00 & 0.00 \\
\hline & Minimum & 4.5 & 0.00 & 0.00 \\
\hline & Maximum & 7.8 & 5.10 & 20.80 \\
\hline & CV (\%) & 12.0 & - & - \\
\hline \multirow{6}{*}{ Sodo Zuria $(N=330)$} & Mean & 5.9 & 0.40 & 2.20 \\
\hline & Std. dev & 0.6 & 0.90 & 4.40 \\
\hline & Median & 5.9 & 0.00 & 0.00 \\
\hline & Minimum & 4.7 & 0.00 & 0.00 \\
\hline & Maximum & 7.4 & 4.10 & 19.50 \\
\hline & CV (\%) & 10.0 & - & - \\
\hline \multirow{8}{*}{ Total $(N=789)$} & Mean & 6.1 & 0.30 & 1.60 \\
\hline & Std. dev & 0.6 & 0.80 & 3.90 \\
\hline & Median & 6.1 & 0.00 & 0.00 \\
\hline & Minimum & 4.5 & 0.00 & 0.00 \\
\hline & Maximum & 8.0 & 5.10 & 20.80 \\
\hline & CV (\%) & 10.0 & - & - \\
\hline & $F_{\text {value }}$ & 49.0 & 26.0 & 27.0 \\
\hline & $p$ & 0.000 & 0.000 & 0.000 \\
\hline
\end{tabular}

Numbers in brackets refer to sample size.

Antagonistic effects could exist when disproportionate quantities of exchangeable cations are present in the soil [63]. The $\mathrm{Ca} / \mathrm{Mg}$ ratio across studied districts using the rating of Eckert [64] has shown low level of $\mathrm{Ca}(1-4)$ on $35 \%$, balanced ratio (4-6) on $60 \%$, and low $\mathrm{Mg}(6-10)$ on $5 \%$ of the samples. The $\mathrm{K} / \mathrm{Mg}$ ratio has been evaluated with consideration of soil textures, in which it is $1: 1$ for loamy soils and $0.7: 1$ for clay soils [65]. In silty loam textured soils of Damot Gale, the K/Mg ratio varied from 0.2 to 1.6 , while the ratio ranged between 0.1 and 1.5 in clay textured soils of Damot Sore and Sodo Zuria district. Accordingly, 47, 57, and $54 \%$ of the silty loam soils, clay soils, and total soil samples, respectively, have shown the potential of $\mathrm{Mg}$ induced $\mathrm{K}$ deficiency. The observed cation order in the exchange complex $(\mathrm{Ca}>\mathrm{Mg}>\mathrm{K}>\mathrm{Na}$ ) could also support the existence of $\mathrm{Mg}$-induced $\mathrm{K}$ deficiency [63]. Hence, fertilizer containing $\mathrm{K}$ is suggested.

In the present study, exchangeable bases showed nonsignificant and very weak correlation with OC, implying that the contribution of soil OM is low for these elements. Hence, the medium to high contents of exchangeable bases could be associated with the variation of parent material mineralogy $[25,66,67]$. Kibet [25] stated that the variation in $\mathrm{Ca}$ and $\mathrm{K}$ concentrations is largely related to the variation in mineralogy of parent rock with high source from K-feldspars followed by kaolinite/1:1 clays, then quartz, and plagioclase. In addition, $\mathrm{Ca}$ and $\mathrm{K}$ are presumed to be originating primarily from parent material, i.e., feldspar as reported by USEPA [67] and Kabata- Pendias and Murkhejee [66].
On the other hand, low soil OM, soil erosion, acidic nature of the soil, continuous removal with crop harvest, and lack of $\mathrm{K}$ containing fertilizer could explain the low level of exchangeable $\mathrm{Ca}, \mathrm{Mg}$, and $\mathrm{K}$ in some of the soil samples. In addition, the presence of moderate to high leaching on sampled soil [39] would also result in low exchangeable cation. In line with this finding, Adesodun et al. [68] reported that continuous cultivation led to reduction, uptake, and leaching of exchangeable cations, especially in acidic tropical soils. Furthermore, breakdown of primary minerals, particularly K-feldspars and plagioclase [69], or depletion in well-drained soils over long periods of pedogenic weathering [72] could cause lower $\mathrm{Ca}$ and $\mathrm{K}$.

Owing to the differences in soil environment, clay, and soil organic matter contents, variation in cation exchange capacity (CEC) within and among districts was recorded (Table 6). However, the mean values across districts were found to be almost similar. The CEC of soils ranged from $3.3 \mathrm{cmol} \mathrm{(+)} \mathrm{kg}^{-1}$ in the silty loam soils of Damot Gale to $50.5 \mathrm{cmol}(+) \mathrm{kg}^{-1}$ in clay soils of Damot Sore. According to Landon [41], the proportions of soil samples (\%) which fall in the very low $(<5)$, low (5-15), moderate (15-25), and high (25-40) CEC content categories were 2, 75, 19, and 4, respectively. Overall, the majority $(83 \%)$ of the soil samples across districts showed medium CEC values.

Cation exchange capacity is highly influenced by soil $\mathrm{pH}$, $\mathrm{OM}$, and clay particles. The CEC of soil could vary with soil $\mathrm{pH}$, if soil has pH-dependent charge edges [27]. Different scholars also reported an increase in the CEC of soils due to high OM 


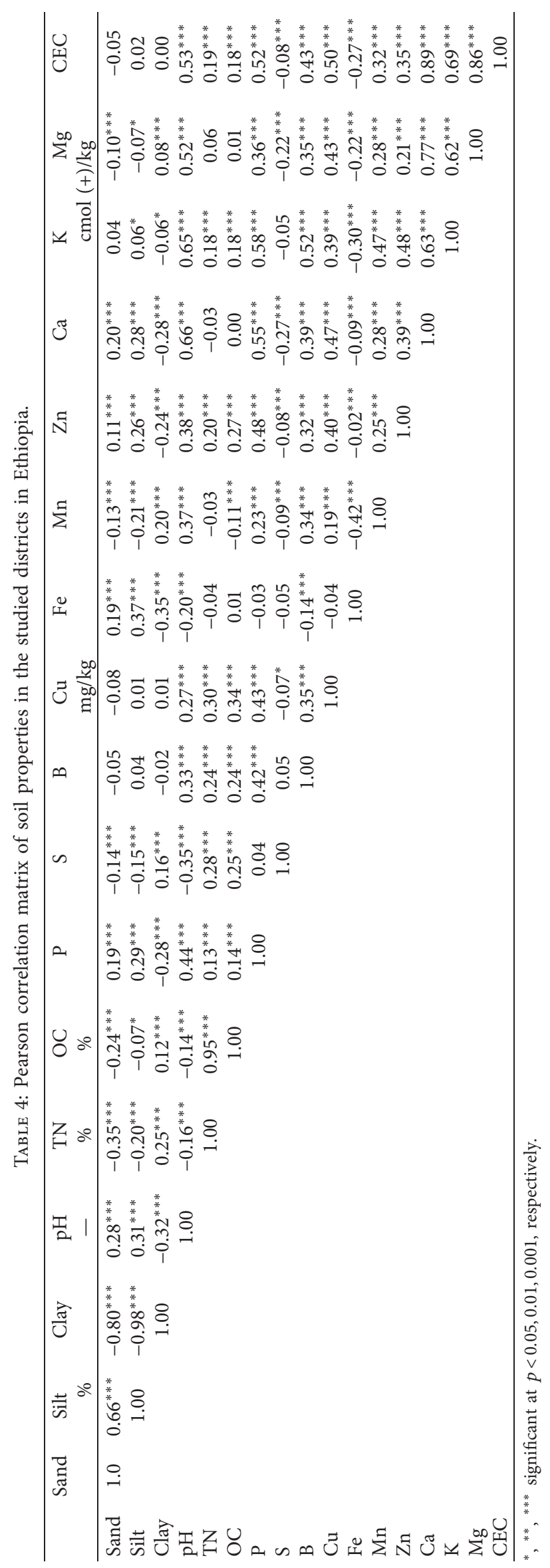


TABLE 5: Descriptive statistics of soil OC, TN, AvP, and $\mathrm{SO}_{4}{ }^{2-}-\mathrm{S}$ for surface soil.

\begin{tabular}{|c|c|c|c|c|c|c|}
\hline Districts & Descriptive statistics & $\begin{array}{c}\mathrm{OC} \\
\%\end{array}$ & $\begin{array}{c}\mathrm{TN} \\
\%\end{array}$ & $\begin{array}{c}\mathrm{C}: \mathrm{N} \text { ratio } \\
-\end{array}$ & $\begin{array}{c}\text { AvP } \\
\mathrm{mg} / \mathrm{kg}\end{array}$ & $\begin{array}{c}\mathrm{SO}_{4}{ }^{2-}-\mathrm{S} \\
\mathrm{mg} / \mathrm{kg}\end{array}$ \\
\hline \multirow{6}{*}{ Damot Gale $(N=243)$} & Mean & 1.89 & 0.12 & 17.2 & 18.3 & 10.2 \\
\hline & Std. dev & 0.69 & 0.06 & 5.6 & 34.8 & 2.9 \\
\hline & Median & 1.80 & 0.12 & 15.5 & 6.3 & 9.7 \\
\hline & Minimum & 0.2 & 0.01 & 8.6 & 0.1 & 4.2 \\
\hline & Maximum & 4.2 & 0.35 & 40.6 & 215.0 & 20.3 \\
\hline & CV (\%) & 37.0 & 50.0 & 33.0 & 190.0 & 28.0 \\
\hline \multirow{6}{*}{ Damot Sore $(N=216)$} & Mean & 2.52 & 0.18 & 14.4 & 9.4 & 11.0 \\
\hline & Std. dev & 0.68 & 0.06 & 2.4 & 25.2 & 3.9 \\
\hline & Median & 2.5 & 0.18 & 14.0 & 3.1 & 10.2 \\
\hline & Minimum & 1.0 & 0.04 & 10.1 & 0.1 & 3.7 \\
\hline & Maximum & 4.4 & 0.35 & 30.9 & 238.1 & 28.2 \\
\hline & CV (\%) & 27.0 & 33.0 & 17.0 & 268.0 & 35.0 \\
\hline \multirow{6}{*}{ Sodo Zuria $(N=330)$} & Mean & 1.9 & 0.14 & 14.2 & 5.6 & 11.3 \\
\hline & Std. dev & 0.69 & 0.07 & 3.3 & 10.0 & 3.7 \\
\hline & Median & 1.9 & 0.14 & 13.4 & 2.9 & 10.9 \\
\hline & Minimum & 0.3 & 0.02 & 7.4 & 0.1 & 4.2 \\
\hline & Maximum & 0.69 & 0.68 & 35.0 & 99.4 & 30.3 \\
\hline & CV (\%) & 36.0 & 50.0 & 23.0 & 179.0 & 33.0 \\
\hline \multirow{7}{*}{ Total $(N=789)$} & Mean & 2.08 & 0.15 & 15.1 & 10.5 & 10.9 \\
\hline & Std. dev & 0.74 & 0.07 & 4.1 & 24.8 & 3.6 \\
\hline & Median & 2.0 & 0.15 & 14.0 & 3.4 & 10.4 \\
\hline & Minimum & 0.2 & 0.01 & 7.4 & 0.1 & 3.7 \\
\hline & Maximum & 6.9 & 0.68 & 40.6 & 238.1 & 30.3 \\
\hline & CV (\%) & 36.0 & 47.0 & 27.0 & 236 & 33.0 \\
\hline & $F_{\text {value }}$ & $60.4^{* * *}$ & $42.6^{* * *}$ & $42.9^{* * *}$ & $19.0^{* * *}$ & $6.4^{* *}$ \\
\hline
\end{tabular}

Numbers in brackets refer to sample size; ${ }^{* *},{ }^{* * *}$ significant at $p<0.01,0.001$, respectively.

TABLE 6: Descriptive statistics of soil exchangeable bases, CEC, and PBS for surface soil.

\begin{tabular}{|c|c|c|c|c|c|c|c|}
\hline District & Descriptive Statistics & $\mathrm{Ca}$ & $\mathrm{Mg}$ & $\begin{array}{c}\mathrm{K} \\
\mathrm{cmol}(+) / \mathrm{kg}\end{array}$ & $\mathrm{Na}$ & CEC & $\begin{array}{c}\text { PBS } \\
\% \\
\end{array}$ \\
\hline \multirow{6}{*}{ Damot Gale $(N=243)$} & Mean & 9.1 & 1.9 & 1.4 & 0.8 & 21.1 & 61.3 \\
\hline & Std. dev & 3.1 & 0.6 & 0.8 & 0.3 & 4.0 & 8.4 \\
\hline & Median & 8.4 & 1.9 & 1.1 & 0.7 & 20.3 & 61.4 \\
\hline & Minimum & 1.5 & 0.2 & 0.1 & 0.1 & 3.3 & 30.5 \\
\hline & Maximum & 19.6 & 4.2 & 3.9 & 2.1 & 34.3 & 80.1 \\
\hline & CV (\%) & 34 & 32 & 57 & 38 & 19 & 14 \\
\hline \multirow{6}{*}{ Damot Sore $(N=216)$} & Mean & 8.3 & 2.3 & 1.4 & 0.8 & 22.6 & 53.8 \\
\hline & Std. dev & 4.9 & 1.4 & 1.0 & 0.3 & 6.1 & 14.9 \\
\hline & Median & 7.1 & 2.0 & 1.0 & 0.7 & 20.9 & 54.4 \\
\hline & Minimum & 2.0 & 0.5 & 0.2 & 0.4 & 13.8 & 19.5 \\
\hline & Maximum & 31.2 & 9.5 & 6.2 & 3.1 & 50.5 & 87.8 \\
\hline & CV (\%) & 59 & 61 & 71 & 38 & 27 & 28 \\
\hline \multirow{6}{*}{ Sodo Zuria $(N=330)$} & Mean & 7.0 & 1.8 & 1.1 & 0.7 & 20.0 & 51.8 \\
\hline & Std. dev & 3.6 & 0.7 & 0.7 & 0.3 & 3.7 & 13.8 \\
\hline & Median & 6.4 & 1.8 & 0.9 & 0.6 & 19.4 & 53.2 \\
\hline & Minimum & 1.1 & 0.2 & 0.2 & 0.2 & 12.4 & 8.8 \\
\hline & Maximum & 31.3 & 4.6 & 4.5 & 2.3 & 43.8 & 86.5 \\
\hline & CV (\%) & 51 & 39 & 64 & 43 & 19 & 27 \\
\hline \multirow{7}{*}{ Total $(N=789)$} & Mean & 8.0 & 2.0 & 1.3 & 0.7 & 21.0 & 55.3 \\
\hline & Std. dev & 4.0 & 0.9 & 0.9 & 0.3 & 4.7 & 13.4 \\
\hline & Median & 7.4 & 1.9 & 1.0 & 0.6 & 20.0 & 56.9 \\
\hline & Minimum & 1.1 & 0.2 & 0.1 & 0.1 & 3.3 & 8.8 \\
\hline & Maximum & 31.3 & 9.5 & 6.2 & 3.1 & 50.5 & 87.8 \\
\hline & CV (\%) & 50 & 45 & 69 & 43 & 22 & 24 \\
\hline & $F_{\text {value }}$ & $20.4^{* * *}$ & $15.2^{* * *}$ & $8.5^{* * *}$ & $13.4^{* * *}$ & $20.7^{* * *}$ & $40.5^{* * *}$ \\
\hline
\end{tabular}

Numbers in brackets refer to sample size; ${ }^{* * *}$ significant at $p<0.001$. 
TABLE 7: Descriptive statistics of soil micronutrients ( $\mathrm{B} \mathrm{Cu}, \mathrm{Fe}, \mathrm{Mn}$, and $\mathrm{Zn}$ ) for surface soils.

\begin{tabular}{|c|c|c|c|c|c|c|}
\hline District & Descriptive statistics & $\mathrm{B}$ & $\mathrm{Cu}$ & $\begin{array}{c}\mathrm{Fe} \\
\mathrm{mg} / \mathrm{kg}\end{array}$ & $\mathrm{Mn}$ & $\mathrm{Zn}$ \\
\hline \multirow{6}{*}{ Damot Gale $(N=243)$} & Mean & 0.56 & 0.47 & 133.0 & 521.0 & 10.59 \\
\hline & Std. dev & 0.30 & 0.41 & 29.0 & 162.0 & 7.13 \\
\hline & Median & 0.48 & 0.40 & 133.0 & 523.0 & 8.80 \\
\hline & Minimum & 0.01 & 0.01 & 22.0 & 84.0 & 1.10 \\
\hline & Maximum & 1.82 & 5.00 & 259.0 & 950.0 & 51.00 \\
\hline & CV $(\%)$ & 54.0 & 87.0 & 22.0 & 31.0 & 67.0 \\
\hline \multirow{6}{*}{ Damot Sore $(N=216)$} & Mean & 0.60 & 0.78 & 131.0 & 510.0 & 9.03 \\
\hline & Std. dev & 0.41 & 0.44 & 42.0 & 160.0 & 5.73 \\
\hline & Median & 0.51 & 0.68 & 124.0 & 490.0 & 7.60 \\
\hline & Minimum & 0.20 & 0.01 & 61.0 & 61.0 & 0.30 \\
\hline & Maximum & 4.97 & 2.66 & 392.0 & 912.0 & 36.80 \\
\hline & CV (\%) & 68 & 56 & 32 & 33 & 63 \\
\hline \multirow{6}{*}{ Sodo Zuria $(N=330)$} & Mean & 0.50 & 0.46 & 120.0 & 599.0 & 7.29 \\
\hline & Std. dev & 0.41 & 0.27 & 55.0 & 223.0 & 8.13 \\
\hline & Median & 0.42 & 0.41 & 104.0 & 616.0 & 5.40 \\
\hline & Minimum & 0.18 & 0.01 & 45.0 & 50.0 & 0.70 \\
\hline & Maximum & 6.90 & 1.42 & 384.0 & 1138 & 117.40 \\
\hline & CV (\%) & 82 & 59 & 46 & 37 & 112 \\
\hline \multirow{7}{*}{ Total $(N=789)$} & Mean & 0.55 & 0.55 & 127.0 & 551.0 & 8.78 \\
\hline & Std. dev & 0.38 & 0.39 & 45.0 & 193.0 & 7.36 \\
\hline & Median & 0.46 & 0.47 & 119.0 & 545.0 & 7.20 \\
\hline & Minimum & 0.01 & 0.01 & 22.0 & 50.0 & 0.30 \\
\hline & Maximum & 6.90 & 5.00 & 392.0 & 1138.0 & 117.40 \\
\hline & CV (\%) & 69 & 71 & 35 & 35 & 84 \\
\hline & $F_{\text {value }}$ & $4.7^{* *}$ & $56.1^{* * *}$ & $7.3^{* *}$ & $18.8^{* * *}$ & $14.8^{* * *}$ \\
\hline
\end{tabular}

Numbers in brackets refer to sample size; ${ }^{* *},{ }^{* * *}$ significant at $p<0.01,0.001$, respectively.

and clay contents [71, 44]. Pearson correlation matrix shows that CEC was positively and significantly correlated with $\mathrm{pH}$ $(r=0.5)$ and OC $(r=0.2)$. The CEC also significantly $(p \leq 0.001)$ correlated with $\mathrm{Ca}(r=0.9), \mathrm{Mg}(r=0.9)$, and $\mathrm{K}$ $(r=0.7)$ (Table 4). However, the relation with the amount of clay was negligible. Hence, the type of clay mineralogy and soil OM might have been the factors that contributed to the CEC values of the studied soils. In accord with this finding, Maria and Yost [28] and Joao et al. [29] reported a reduction in soil $\mathrm{CEC}$ as soil $\mathrm{pH}$ became lower. Generally, moderate CEC values imply that the soil has moderate buffering capacity against the induced changes.

The percentage base saturation (PBS) in the present study followed the trend of exchangeable bases. It varied from $9 \%$ in Sodo Zuria soils to $88 \%$ in soils of Damot Sore district (Table 6). However, as per the ratings proposed by [28], 15, 45, 39, and $1 \%$ had very low $(<20)$, low (20-40), medium (40-60), high (60-80), and very high PBS (80-100\%), respectively. The values recorded indicated that soils in the study area are moderately to strongly leached [39].

3.2.5. Micronutrient Contents. The range of micronutrient content (mg/kg) was as follows: B (0.01 to 6.9), $\mathrm{Cu}$ (0.01 to 5), $\mathrm{Fe}$ (22 to 392 ), $\mathrm{Mn}$ (50 to 1138 ), and $\mathrm{Zn}$ (0.3 to 117) (Table 7). Considering the ratings proposed for Ethiopian soils by EthioSIS [40], about 57, 30, and 13\% samples across districts had very low $(<0.5)$, low $(0.5-0.8)$, and optimum $(0.8-2.0 \mathrm{mg} /$ $\mathrm{kg}) \mathrm{B}$ content, respectively. The result regarding $\mathrm{Cu}$ content also revealed that about 53,37 , and $10 \%$ of the entire soil samples qualified to be very low $(<0.5)$, low $(0.5-0.9)$, and optimum $(1-20 \mathrm{mg} / \mathrm{kg})$, respectively. The content of $\mathrm{Fe}$ was optimum except some localized deficiencies. Overall, about 7 , 91, and $2 \%$ of the soil samples had low (60-80), optimum (80-300), and high Fe (300-400 mg/kg), respectively. Soil Mn (mg/kg) in all samples was above 25, which is optimum according to the EthioSIS ratings criteria [40]. Furthermore, the present finding indicated the sufficiency of $\mathrm{Zn}$. In terms of proportion, $3,65,26$, and $6 \%$ of the soil samples across districts have low (1-1.5), optimum (1.5-10), high (10-20), and very high (>20 mg/kg) Zn levels, respectively.

The variation in soil micronutrients could be linked with soil $\mathrm{pH}, \mathrm{OM}$, and soil management differences. Soil $\mathrm{pH}$ has an influence on the solubility and availability of soil micronutrients. This was evident in the significant $(p \leq 0.01)$ correlation between soil $\mathrm{pH}$ and $\mathrm{B}(r=0.3), \mathrm{Cu}(r=0.3), \mathrm{Fe}$ $(r=-0.2), \mathrm{Mn}(r=0.4)$, and $\mathrm{Zn}(r=0.2)$. Soil OC content also indicated a significant $(p \leq 0.01)$ correlation with B $(r=0.2)$, $\mathrm{Cu}(r=0.3), \mathrm{Mn}(r=0.1)$, and $\mathrm{Zn}(r=0.3)$ (Table 4$)$.

Overall, B and $\mathrm{Cu}$ contents in all sampled soils were found to yield limiting nutrients whereas Fe, Mn, and $\mathrm{Zn}$ levels were sufficient for crop production. Acidic $\mathrm{pH}$, loss through leaching, low B absorbing capacity of soil, and parent material containing low $B$ might cause low $B$ [72]. In soils, soluble B is mainly present in the form of boric acid B $(\mathrm{OH})_{3}$. In highly weathered soils like the study area, this anion is adsorbed by $\mathrm{Al} / \mathrm{Fe}$ oxides and clay minerals. Hence, soils would often show low B content, and crops grown on 
these soils may suffer from B deficiency [73]. Furthermore, intensive cultivation of soils, lower application rate of manure, and nonuse of $\mathrm{B}$ containing fertilizer could also aggravate the $\mathrm{B}$ deficiency $[57,74]$.

The $\mathrm{Cu}$ deficiency could be linked with low soil OM, practice of intensive cropping systems, acidic nature of the soil, and nonuse of $\mathrm{Cu}$ containing fertilizer. Chesworth [73] and Bitondo et al. [74] reported that organic matter complexes can retain substantial proportion of micronutrients. This is significantly $(p<0.001)$ supported by the positive correlation of OC with $\mathrm{B}(r=0.24)$ and $\mathrm{Cu}(r=0.34)$ (Table 4). Hence, the low level of soil OM would contribute to the low level of these elements. Correspondingly, the research under intensive cropping systems of Venezuela by Rodríguez and Ramírez [75] reported $\mathrm{Cu}$ deficiency on acid soils $(\mathrm{pH}<6.5)$, and it accounted for low level of soil OM. Reports also indicated $\mathrm{Cu}$ deficiency in some Nitisols of Ethiopia [36, 57, 76]: [53].

The sufficient levels of Fe and Mn could be linked with acidic nature of the soils. In agreement with the current findings, Oyinlola and Chude [72] indicated higher solubility and availability of micronutrients like Fe, Mn, and $\mathrm{Zn}$ under acidic conditions ( $\mathrm{pH}$ of 5.0 to 6.5). Furthermore, the higher Fe content might also be explained by the higher content of raw mineralogy [25]. In addition, higher Mn levels are often found in soils rich in $\mathrm{Fe}$ [25]. Zinc is reported to be generally associated with $\mathrm{Al}$ - and Fe-containing minerals such as feldspars, micas, pyroxenes, and amphiboles [69].

3.3. Variability among Soil Parameters. The measured soil parameters of agricultural soils within and across districts showed considerable variability ranging between $10 \%$ and 235\% (Tables 2, 3, 5-7). Soil pH was relatively less variable while available $\mathrm{P}$ was found to be highly variable. Similar trend was reported by Iticha and Takele [2]. According to Amuyou et al. [24] soil parameters having CV $<20 \%$ showed low variability, whereas those with $20<\mathrm{CV} \leq 50 \%$ showed moderate variability. Similarly, soil properties having $\mathrm{CV}>50 \%$ showed high variability compared to their mean. Variability among parameters was ascribed to (1) random pick-up of large number of data and (2) remarkably high variation of topography, management, land use types, and inherent properties like texture and $\mathrm{pH}$. Similarly, in soil fertility survey researches, CV values ranging from 13 (bulk density and $\mathrm{pH}$ ) to 585\% (mineral N) [77], 0.3 (exchangeable $\mathrm{K})$ to $118.64 \%(\mathrm{Zn})[78]$, and $5.37(\mathrm{pH})$ to $100 \%(\mathrm{ex}-$ changeable K) [79] were reported.

\section{Conclusion}

Low soil OC; total N; available P, K, S; and micronutrients (B and $\mathrm{Cu}$ ) were identified as a major limiting factors in the study areas. In addition, in some places there was also strong acidity. Both inherent soil-landscape (e.g., clay mineralogy and topography) and human-induced factors (e.g., unwise soil management practices including residue removal, continues tillage, excessive grazing, and inadequate fertilizer) might be causes of farmland constraints. The soil parameters are highly variable and also location specific. The turning point to solve the problem should be restoring, maintaining, and increasing the fertility status of the soils. Location-specific study like this offers detailed information about soils of a particular field and can be used to make informed decision for precision fertilization and liming. Thus, it overcomes blanket recommendation approaches. Therefore, soil management interventions such as soil conservation, application of sufficient organic and inorganic fertilizers, and lime in acidic soils are recommended to restore soil fertility and improve crop productivity.

\section{Data Availability}

The data used to support the findings of this study are available from the corresponding author upon request.

\section{Conflicts of Interest}

The authors declare that they have no conflicts of interest.

\section{Authors' Contributions}

FL collected, analyzed, and interpreted the data, which was part of his Doctoral thesis on soil science at Haramaya University, Ethiopia. KK helped to draft the manuscript. Both authors read and approved the final manuscript.

\section{Acknowledgments}

The authors would like to thank Ministry of Education (MOE) for the scholarship and Ethiopian Soil Information System (EthioSIS) at the Agricultural Transformation Agency (ATA) for financial support. Acknowledgments also go to the late Prof. Tekalign Mamo for his appreciated contribution, and the authors wish that his soul rests peacefully. The authors thank Ermiyas Elka, Simon Yohannes, and the late Daninel Milkyas for their support during sample collection. The authors are very grateful for all the assistance, knowledge, and experience they have received from the farmers in Damot Gale, Damot Sore, and Sodo Zuria districts.

\section{References}

[1] F. Laekemariam, K. Kibret, T. Mamo, and H. Shiferaw, "Accounting spatial variability of soil properties and mapping fertilizer types using geostatistics in southern Ethiopia," Communications in Soil Science and Plant Analysis, vol. 49, no. 1, pp. 124-137, 2018.

[2] B. Iticha and C. Takele, "Digital soil mapping for site-specific management of soils," Geoderma, vol. 351, pp. 85-91, 2019.

[3] R. Panday, R. Babu Ojha, D. Chalise, S. Das, and B. Twanabasu, "Spatial variability of soil properties under different land use in the Dang district of Nepal," Cogent Food \& Agriculture, vol. 5, no. 1, Article ID 1600460, 2019.

[4] P. Tittonell, A. Muriuki, C. J. Klapwijk, K. D. Shepherd, R. Coe, and B. Vanlauwe, "Soil heterogeneity and soil fertility gradients in smallholder farms of the East African highlands," 
Soil Science Society of America Journal, vol. 77, no. 2, pp. 525-538, 2013.

[5] E. Elias, P. F. Okoth, and E. M. A. Smaling, "Explaining bread wheat (Triticum aestivum) yield differences by soil properties and fertilizer rates in the highlands of Ethiopia," Geoderma, vol. 339, pp. 126-133, 2019.

[6] F. Laekemariam, K. Kibebew, T. Mamo, E. Karltun, and H. Gebrekidan, "Physiographic characteristics of agricultural lands and farmers' soil fertility management practices in Wolaita zone, Southern Ethiopia," Environmental Systems Research, vol. 5, no. 1, p. 24, 2016.

[7] Z. Adimassu, S. Langan, R. Johnston, W. Mekuria, and T. Amede, "Impacts of soil and water conservation practices on crop yield, run-off, soil loss and nutrient loss in Ethiopia: review and synthesis," Environmental Management, vol. 59, no. 1, pp. 87-101, 2017.

[8] IFPRI, Fertilizer and Soil Fertility Potential in Ethiopia Constraints and Opportunities for Enhancing the System, IFPRI, Washington, DC, USA, 2010.

[9] E. Teklu, T. O. Williams, and L. Fanuel, "Integrated soil, water and agronomic management effects on crop productivity and selected soil properties in Western Ethiopia," International Soil and Water Conservation Research, vol. 6, pp. 305-316, 2018.

[10] A. Haileslassie, J. Priess, E. Veldkamp, D. Teketay, and J. P. Lesschen, "Assessment of soil nutrient depletion and its spatial variability on smallholders' mixed farming systems in Ethiopia using partial versus full nutrient balances," Agriculture, Ecosystems \& Environment, vol. 108, no. 1, pp. 1-16, 2005.

[11] T.-G. Vågen, L. A. Winowiecki, J. E. Tondoh, L. T. Desta, and T. Gumbricht, "Mapping of soil properties and land degradation risk in Africa using MODIS reflectance," Geoderma, vol. 263, pp. 216-225, 2016.

[12] B. Tesfaye, Understanding farmers: explaining soil and water conservation in Konso, Wolaita, and Wollo, Ethiopia, Ph.D. thesis, Wageningen University and Research Center, Wageningen, Netherlands, 2003.

[13] FAO, "World reference base for soil resources. International soil classification system for naming soils and creating legends for soil maps," World soil resources reports No. 106, FAO, Rome, Italy, 2014.

[14] KIC, Munsell Soil Color Charts Baltimore, Kollomorgen Instruments Corporation, Radford, VI, USA, 2000.

[15] J. M. Anderson and J. S. I. Ingram, Tropical soil biology and fertility: A Handbook of Methods, CAB International, Wallingford, UK, 2nd edition, 1993.

[16] C. Stefano, D. V. Ferro, and S. Mirabile, "Comparison between grain-size analysis using laser diffraction and sedimentation methods," Biosystems Engineering, vol. 106, pp. 205-215, 2010.

[17] Horiba Ltd., NextGen Project, Horiba Ltd., Kyoto, Japan, 2010.

[18] R Core Team, R: A Language and Environment for Statistical Computing, R Foundation for Statistical Computing, Vienna, Austria, 2013.

[19] R. Mylavarapu, UF/IFAS Extension Soil Testing Laboratory (ESTL) Analytical Procedures and Training Manual, University of Florida, Gainesville, FL, USA, 2009.

[20] S. Sahlemedhin and B. Taye, Procedures for Soil and Plant Analysis, National Soil Research Center, EARO, Addis Ababa, Ethiopia, 2000.

[21] A. Mehlich, "Mehlich 3 soil test extractant: a modification of Mehlich 2 extractant," Communications in Soil Science and Plant Analysis, vol. 15, no. 12, pp. 1409-1416, 1984.
[22] E. Karltun, T. Mamo, Taye Bekele, S. Gameda, and S. Kidanu, Towards Improved Fertilizer Recommendations in Ethiopia-Nutrient Indices for Categorization Of Fertilizer Blends from Ethiosis Woreda Soil Inventory Data, Ethiopian Soil Information System (EthioSIS), Addis Ababa, Ethiopia, 2013.

[23] Bruker Optik GMbH, Opus Release 7 [Software], Bruker Optik GMbH, Ettlingen, Germany, 2011.

[24] U. A. Amuyou, E. B. Eze, P. A. Essoka, J. Efiong, and O. O. Egbai, "Spatial variability of soil properties in the Obudu mountain region of southeastern Nigeria," International Journal of Humanities and Social Science, vol. 3, no. 15, 2013.

[25] T. E. Kibet, Prediction of soil properties for agricultural and environmental applications from infrared and $X$-ray soil spectral properties, University of Hohenheim, Stuttgart, Germany, Ph.D. dissertation, 2013.

[26] O. Giday, H. Gibrekidan, and T. Berhe, "Soil fertility characterization in vertisols of Southern Tigray, Ethiopia," Advances in Plants and Agriculture Research, vol. 2, no. 1, pp. 1-7, 2015.

[27] J. L. Havlin, J. D. Beaton, S. L. Tisdale, and W. L. Nelson, Soil Fertility and Fertilizers: An Introduction to Nutrient Management, Prentice-Hall, Upper Saddle River, NJ, USA, 7th edition, 2009.

[28] R. M. Maria and R. Yost, "A survey of soil fertility status of four agroecological zones of Mozambique," Soil Science, vol. 171, no. 11, pp. 902-914, 2006.

[29] C. M. Joao, C. C. Cerri, R. Lal, W. A. Dick, M. C. Piccolo, and B. E. Feig, "Soil organic carbon and fertility interactions affected by a tillage chronosequence in a Brazilian oxisol," Soil and Tillage Research, vol. 104, no. 1, pp. 56-64, 2009.

[30] A. Kidanemariam, H. Gebrekidan, T. Mamo, and K. Kibret, "Impact of altitude and land use type on some physical and chemical properties of acidic soils in Tsegede highlands, Northern Ethiopia," Open Journal of Soil Science, vol. 2, no. 3, pp. 223-233, 2012.

[31] I. M. Tabu, R. K. Obura, A. Bationo, and L. Nakhone, "Effects of farmers' management practices on soil properties and maize yield," Journal of Agronomy, vol. 4, no. 4, pp. 293-299, 2005.

[32] A. Desbiez, R. Matthews, B. Tripathi, and J. Ellis-Jones, "Perceptions and assessment of soil fertility by farmers in the mid-hills of Nepal," Agriculture, Ecosystems \& Environment, vol. 103, no. 1, pp. 191-206, 2004.

[33] B. Pound and E. Jonfa, Policy And Research Series, Soil Fertility Practices In Wolaita Zone, Southern Ethiopia: Learning From Farmers, Farm Africa, London, UK, 2005.

[34] A. Haileslassie, J. A. Priess, E. Veldkamp, and J. P. Lesschen, "Smallholders' soil fertility management in the central highlands of Ethiopia: implications for nutrient stocks, balances and sustainability of agro ecosystems," Nutrient Cycling in Agroecosystems, vol. 75, no. 1-3, pp. 135-146, 2006.

[35] A. Young, Tropical Soils and Soil Survey, Cambridge University Press, London, UK, 1976.

[36] A. Kiflu and S. Beyene, "Effects of different land use systems on selected soil properties in South Ethiopia," Journal of Soil Science and Environmental Management, vol. 4, no. 5, pp. 100-107, 2013.

[37] P. C. Oguike and J. S. C. Mbagwu, "Variations in some physical properties and organic matter content of soils of coastal plain sand under different land use types," World Journal of Agricultural Sciences, vol. 5, no. 1, pp. 63-69, 2009.

[38] B. Gajic, G. Dugalic, and N. Djurovic, "Comparison of SOM content, aggregate composition and water stability of gleyic 
fluvisol from adjacent forest and cultivated areas," Agronomy Research, vol. 4, no. 2, pp. 499-508, 2006.

[39] P. Hazelton and B. Murphy, Interpreting Soil Test Results. What Do All the Numbers Mean?, CSIRO Publishing, Clayton, Australia, 2007.

[40] EthioSIS, Soil Fertility Status and Fertilizer Recommendation Atlas for Tigray Regional State, Ethiopia, Ethiopia Soil Information System, Addis Ababa, Ethiopia, 2014.

[41] J. R. Landon, Booker Tropical Soil Manual: A Handbook for Soil Survey and Agricultural Land Evaluation in the Tropics and Subtropics, Routledge, Abingdon, UK, 2014.

[42] M. C. Amacher, K. P. O'Neil, and C. H. Perry, Soil Vital Signs: A New Soil Quality Index (SQI) for Assessing Forest Soil Health, US Department of Agriculture, Forest Service, Rocky Mountain Research Station, Fort Collins, CO, USA, 2007.

[43] A. E. Hartemink, "Assessing soil fertility decline in the tropics using soil chemical data," Advances in Agronomy, Elsevier, vol. 89, pp. 179-225, Amsterdam, Netherlands, 2006.

[44] Y. G. Selassie, F. Anemut, and A. Solomon, "The effects of land use types, management practices and slope classes on selected soil physico-chemical properties in Zikre watershed, NorthWestern Ethiopia," Environmental Systems Research, vol. 4, no. 1, pp. 1-7, 2015.

[45] F. Khan, M. Waliullah, W. M. Naeem, and A. U. Bhatti, "Effect of slope steepness and wheat crop on soil, runoff and nutrient losses in eroded land of Malakand agency, Nwfp, Pakistan," Sarhad Journal of Agriculture, vol. 23, no. 1, pp. 101-106, 2007.

[46] G. O. Islabão, M. A. B. Pinto, L. P. R. Selau, L. C. Vahl, and L. C. Timm, "Characterization of soil chemical properties of strawberry fields using principal component analysis," Revista Brasileira de Ciência do Solo, vol. 37, no. 1, pp. 168-176, 2012.

[47] R. Cardelli, F. Marchini, and A. Saviozzi, "Soil organic matter characteristics, biochemical activity and antioxidant capacity in Mediterranean land use systems," Soil and Tillage Research, vol. 120, pp. 8-14, 2012.

[48] M. Alexandra, R. Charles, B. Jeangros, and S. Sinaj, "Effect of organic fertilizers and reduced-tillage on soil properties, crop nitrogen response and crop yield: results of a 12-year experiment in Changins, Switzerland," Soil and Tillage Research, vol. 126, pp. 11-18, 2013.

[49] J. L. Moir and D. J. Moot, "Soil pH, exchangeable aluminum and lucerne yield responses to lime in a south island high country soil," Proceedings of the New Zealand Grassland Association, vol. 72, pp. 191-196, 2010.

[50] B. Taye, Estimation of Lime Requirement. Training Manual for Regional Soil Testing Laboratory Heads and Technicians, National Soil Testing Center, Ministry of Agriculture and Rural Development, Addis Ababa, Ethiopia, 2008.

[51] T. Yitbarek, H. Gebrekidan, K. Kibret, and S. Beyene, "Impacts of land use on selected physicochemical properties of soils of Abobo area, Western Ethiopia," Agriculture, Forestry and Fisheries, vol. 2, no. 5, pp. 177-183, 2013.

[52] FAO, Topsoil Characterization for Sustainable Land Management (Draft Report), Land and Water Development Division, Soil Resources, Management and Conservation Service, FAO, Rome, Italy, 1998.

[53] G. Abera and E. Wolde-Meskel, "Soil properties, and soil organic carbon stocks of tropical andosol under different land uses," Open Journal of Soil Science, vol. 3, no. 3, pp. 153-162, 2013.

[54] T. Gebrelibanos and M. Assen, "Effects of land-use/cover changes on soil properties in a dry land watershed of Hirmi and its adjacent agro ecosystem: Northern Ethiopia,"
International Journal of Geosciences Research, vol. 1, no. 1, pp. 45-57, 2013.

[55] Z. Tiejun, Y. Wang, X. Wang, Q. Wang, and J. Han, "Organic carbon and nitrogen stocks in reed meadow soils converted to alfalfa fields," Soil and Tillage Research, vol. 105, no. 1, pp. 143-148, 2007.

[56] J. D. Álvarez-Solís, P. M. Rosset, B. M. Díaz-Hernández, H. Plascencia-Vargas, and R. A. Rice, "Soil fertility differences across a land-use intensification gradient in the highlands of Chiapas, Mexico," Biology and Fertility of Soils, vol. 43, no. 3, pp. 379-386, 2006.

[57] A. Nigussie and E. Kissi, "Physicochemical characterization of Nitisol in southwestern Ethiopia and its fertilizer recommendation using NuMaSS," Global Advanced Research Journal of Agricultural Science, vol. 1, no. 4, pp. 66-73, 2012.

[58] F. Itanna, "Sulfur distribution in five Ethiopian rift valley soils under humid and semi-arid climate," Journal of Arid Environments, vol. 62, no. 4, pp. 597-612, 2005.

[59] K. F. Nand, V. C. Baligar, and C. A. Jones, Growth and Mineral Nutrition of Field Crops, Taylor and Francis Group, London, UK, 3rd edition, 2011.

[60] D. Solomon, J. Lehmann, M. Tekalign, F. Fritzsche, and W. Zech, "Sulfur fractions in particle-size separates of the subhumid Ethiopian highlands as influenced by land use changes," Geoderma, vol. 102, no. 1-2, pp. 41-59, 2001.

[61] T. Mamo and I. Haque, "Sulphur investigations in some Ethiopian soils," East African Agricultural and Forestry Journal, vol. 52, no. 3, pp. 148-156, 1987.

[62] J. Arshad, Y. S. Moon, and M. Z. Abdin, "Sulfur. A general overview and interaction with nitrogen," Australian Journal of Crop Science, vol. 4, pp. 523-529, 2010.

[63] F. Laekemariam, K. Kibebew, and H. Shiferaw, "Potassium (K)-to-magnesium $(\mathrm{Mg})$ ratio, its spatial variability and implications to potential Mg-induced $\mathrm{K}$ defciency in nitisols of Southern Ethiopia," Agriculture and Food Security, vol. 7, no. 1, p. 13, 2018.

[64] D. J. Eckert, "Soil test interpretations. Basic cation saturation ratios and sufficiency levels," in Soil Testing: Sampling, Correlation, Calibration and Interpretations, J. R. Brown, Ed., pp. 53-64, Soil Science Society of America, Madison, WI, USA, 1987.

[65] V. Loide, "About the effect of the contents and ratios of soil's available calcium, potassium and magnesium in liming of acid soils," Agronomy Research, vol. 2, no. 1, pp. 71-82, 2004.

[66] A. Kabata-Pendias and A. B. Mukherjee, Trace Elements from Soil to Human, Springer-Verlag, Berlin, Germany, 2007.

[67] USEPA, Innovative Technology Verification Report. XRF Technologies for Measuring Trace Elements in Soil and Sediment, Rontec PicoTAX XRF Analyzer, United States Environmental Protection Agency, Office of Research and Development, Washington DC, USA, 2006.

[68] J. Adesodun, E. Adeyemi, and C. Oyegoke, "Distribution of nutrient elements within water-stable aggregates of two tropical agro-ecological soils under different land uses," Soil and Tillage Research, vol. 92, no. 1-2, pp. 190-197, 2007.

[69] J. A. Acosta, S. Martínez-Martínez, A. Faz, and J. Arocena, "Accumulations of major and trace elements in particle size fractions of soils on eight different parent materials," Geoderma, vol. 161, no. 1-2, pp. 30-42, 2011.

[70] J. J. Marques, D. G. Schulze, N. Curi, and S. A. Mertzman, "Trace element geochemistry in Brazilian cerrado soils," Geoderma, vol. 121, no. 1-2, pp. 31-43, 2004. 
[71] A. Nigussie and E. Kissi, "The contribution of coffee agroecosystem to soil fertility in Southwestern Ethiopia," African Journal of Agricultural Research, vol. 7, no. 1, pp. 74-81, 2012.

[72] E. Y. Oyinlola and V. O. Chude, "Status of available micronutrients of the basement complex rock-derived alfisols in northern Nigeria Savanna," Tropical and Subtropical Agroecosystems, vol. 12, pp. 229-237, 2010.

[73] W. Chesworth, Encyclopedia of Soil Science, Springer, Berlin, Germany, 2007.

[74] D. Bitondo, F. O. Tabi, S. S. A. Kengmegne, M. Ngoucheme, and A. D. MvondoZe, "Micronutrient concentrations and environmental concerns in an intensively cultivated typic dystrandept in Mount Bambouto, Cameroon," Open Journal of Soil Science, vol. 3, no. 6, pp. 283-288, 2013.

[75] B. Rodríguez and R. Ramírez, "A soil test for determining available copper in acidic soils of Venezuela," Interciencia, vol. 30, no. 6, 2005.

[76] T. Baissa, Assessment of micronutrient status of nitisols and andisols in some selected areas of Ethiopia for maize production, Graduate School, Kasetsart University, Bangkok, Thailand, Ph.D. dissertation, 2004.

[77] C. A. Cambardella, T. B. Moorman, J. M. Novak et al., "Fieldscale variability of soil properties in central Iowa soils," Soil Science Society of America Journal, vol. 58, no. 5, pp. 15011511, 1994.

[78] M. Nourzadeh, M. H. Mahdian, M. J. Malakouti, and K. Khavazi, "Investigation and prediction spatial variability in chemical properties of agricultural soil using geostatistics," Archives of Agronomy and Soil Science, vol. 58, no. 5, pp. 461-475, 2012.

[79] S. K. Behera and A. K. Shukla, "Spatial distribution of surface soil acidity, electrical conductivity, soil organic carbon content and exchangeable potassium, calcium and magnesium in some cropped acid soils of India," Land Degradation \& Development, vol. 26, no. 1, pp. 71-79, 2015. 